\title{
The Role of Civic Identity in the Evolution of Relations Between Serbian and Croatian Civil Societies
}

\author{
A. Djokic ${ }^{1}$, G. Pichelin ${ }^{1,2}$ \\ ${ }^{1}$ Peoples' Friendship University of Russia (RUDN University), Moscow, Russian Federation \\ ${ }^{2}$ Sciences Po Bordeaux, Bordeaux France
}

\begin{abstract}
For decades, Croats and Serbs lived together in a common political construction: Yugoslavia. It is difficult to date the appearance of animosity between Croats and Serbs. Nevertheless, two events proved particularly traumatic for their relations. The Second World War, when the Ustasha led a genocide against the Serbs, and the 1991-1995 war, when the two sides fought a merciless civil war. This article examines the evolution of relations between Serbian and Croatian civil societies from the beginning of the Yugoslavian project to 2021 and how the rise of civic identity in the future might help the process of reconciliation. The main hypothesis of the article is that the failure to construct a viable Yugoslavian civic identity in the past is the cause of ethnic tensions during the 90s. The article entails both qualitative and quantitative methods through which the authors offer explanations about the failure to construct a common Yugoslavian civic identity, how this failure impacted the relations between Serbian and Croatian civil societies, and, finally, what are the prospects of reconciliation and constructing civic identities in the newly formed countries of Serbia and Croatia. Today, relations between the two civil societies remain tense. Serbs in Croatia and Croats in Serbia are subject to unsystematic discrimination, which hinders exchanges between the two countries. This study shows that Serbian and Croatian citizens under 35 years of age, mainly agree that tensions exist. Nevertheless, two-thirds of those questioned in Serbia and three-quarters of those questioned in Croatia believe that reconciliation is possible. This reconciliation becomes even more realistic since an overwhelming majority in both groups want reconciliation.
\end{abstract}

Keywords: Ethnic conflict, civic identity, reconciliation, Serbia, Croatia, Balkans

For citation: Djokic, A., \& Pichelin, G. (2021). The role of civic identity in the evolution of relations between Serbian and Croatian civil societies. RUDN Journal of Political Science, 23(4), 675-691. DOI: $10.22363 / 2313-1438-2021-23-4-675-691$

Acknowledgements: The reported study was funded by RFBR and SC RA, project 20-511-05025 "The development of civic identity in the post-Soviet space: trends, challenges, risks (on the example of Russia and Armenia)".

(C) Djokic A., Pichelin G., 2021

(c) () This work is licensed under a Creative Commons Attribution 4.0 International License https://creativecommons.org/licenses/by/4.0/ 


\title{
Роль гражданской идентичности в развитии отношений между сербским и хорватским гражданскими обществами
}

\author{
А. Джокич ${ }^{1}$, Г. Пишлен ${ }^{1,2}$ \\ ${ }^{1}$ Российский университет дружбы народов, Москва, Российская Федерация \\ ${ }^{2}$ Институт политических исследований Сьянс По Бордо, Бордо, Франция
}

\begin{abstract}
Аннотация. На протяжении десятилетий хорваты и сербы жили в общей политической конструкции - Югославии. Трудно датировать появление напряженности между этими народами. Тем не менее два события оказались особенно травматичными для их отношений: Вторая мировая война, когда Усташи устроили геноцид против сербов, и вооруженный конфликт 1991-1995 годов, когда обе стороны вели беспощадную войну. В статье исследуется эволюция отношений между сербским и хорватским гражданскими обществами с начала реализации югославского проекта до 2021 года и то, каким способом построение гражданской идентичности может помочь процессу примирения. Главная гипотеза исследования - неуспех в построении жизнеспособной югославской гражданской идентичности в прошлом является причиной межэтнической напряженности в 1990-е годы. Используются как качественные, так и количественные методы, с помощью которых авторы предлагают варианты объяснения неспособности построить общую югославскую гражданскую идентичность, а также того, как эта неудача повлияла на отношения между сербским и хорватским гражданскими обществами и, наконец, каковы перспективы примирения и построения гражданской идентичности в новообразованных странах Сербии и Хорватии. Сегодня отношения между двумя гражданскими обществами остаются напряженными. Сербы в Хорватии и хорваты в Сербии подвергаются бессистемной дискриминации, что затрудняет обмены между двумя странами. Это исследование показывает, что граждане Сербии и Хорватии в возрасте до 35 лет в основном согласны с существованием напряженности. Тем не менее две трети опрошенных в Сербии и три четверти опрошенных в Хорватии считают, что примирение возможно. Данное примирение становится еще более реалистичным, поскольку подавляющее большинство респондентов в обеих группах желает примирения.
\end{abstract}

Ключевые слова: этнический конфликт, гражданская идентичность, примирение, Сербия, Хорватия, Балканы

Для цитирования: Djokic A., Pichelin G. The role of civic identity in the evolution of relations between Serbian and Croatian civil societies // Вестник Российского университета дружбы народов. Серия: Политология. 2021. Т. 23. № 4. C. 675-691. DOI: 10.22363/2313-1438-202123-4-675-691

Благодарности: Статья подготовлена при финансовой поддержке РФФИ и КН РА в рамках научного проекта № 20-511-05025 - арм_а «Развитие гражданской идентичности на постсоветском пространстве: тенденции, вызовы, риски (на примере России и Армении)».

\section{Introduction}

After the Holocaust, Europe thought that it would never witness such atrocities again. Nevertheless, people in Yugoslavia were discriminated against due to their nationalities in the late 80 's. Concentration camps reappeared and thousands of mass graves were dug. The year 1991 marked a division between the Croats and the Serbs. These two peoples, although different, geographically nested for centuries, 
shared the Serbo-Croatian language and common ethnic rooths which were a symbol of their unification. The failure of the communist political project gave way to nationalist rhetoric from all sides. This led to the belief that the two peoples' differences had become too great to overcome. Therefore, the existence of a common political project could only lead to failure. The construction of a viable Yugoslavian civic identity failed to form during the communist regime which ruled Yugoslavia from 1945-1992 mainly because of the lack of a free and democratic political institutions and civil society. The Croats, who were Catholics and mainly spoke the Iekavian dialect of Serbo-Croatian, opposed the Serbs, who were Orthodox and mainly spoke the Ekavian dialect of Serbo-Croatian. The hope for the common political project ended when the Croats decided to declare their independence. Milosevic, then President of Serbia, presented himself as a defender of the Serbs of Croatia, who feared for their security. The once Yugoslav oriented state-media in Zagreb and Belgrade started to spread nationalist rhetoric which fueled distrust and hatred between Croats and Serbs. Fighting broke out between the two peoples. The Yugoslav army, mainly composed of Serbs, took sides with the Serbs, who wanted to remain in Yugoslavia. Old grudges resurfaced and nationalist militias emerged on both sides. The Croats were referred to by the Serbs as Ustasha, which was the fascist movement that actively collaborated with Hitler. In response, the Serbs were dubbed Chetniks, the Serbian nationalist forces during World War II.

Today the two sides disagree on the nature of the conflict. The Serbs refer to it as a civil war, while the Croats call it an international war. Surely, it is an interethnic conflict. It can be defined as a localized conflict within a country between groups that "force the choice of those they consider to be its members" [Hobsbawm 1993]. A polarization is exercised so that group members are forced "to consider all members of all other groups as traitors or enemies" [Hobsbawm 1993]. As a consequence, they then perceive their own group as the only protection against threats.

After studying the tumultuous past, in order to understand the relations between the Croats and the Serbs, it will be appropriate to look at the results of a field survey conducted in both civil societies. The definition of civil society formulated by Jean Cohen and Andrew Arato, includes "families, informal groups, and voluntary associations whose plurality and autonomy allow for a certain variety of life forms" [Pirotte 2018]. This definition has the advantage of not giving too much importance to the State without putting it aside either. As Habermas explains, it will then come to "institutionalize the discussions (emanating from civil societies) that propose to resolve the problems that arise concerning subjects of general interest" [Pirotte 2018]. This object of study was prioritized over inter-state relations which do not always reflect the reality of the quality of exchanges between two peoples.

On the definition of civic identity - it involves formation and negotiation of personal and group identities as they relate to presence, role, and participation in 
public life. Civic identity is a particularly important factor in civic engagement and participation in democratic deliberation [Jackson, Hogg 2010]. Civic identity is approached in this paper as a general identity through which the citizens of certain political structures (such as the state) consider themselves to be citizens of a certain nation, rather than putting their ethnic or religious identity at the forefront. The main premise of the article is that ethnic tensions were allowed to spread because of the failure to construct a shared Yugoslavian civic identity which ultimately led to a bloody breakup of the state and civil war. To this day the newly formed Western Balkan states that emerged from the ashes of Yugoslavia position themselves as nation-states and are thus unable to construct any viable form of civic identity. Nevertheless, as our field research goes to show, the younger generations of both Croats and Serbs aspire to reconciliation and peaceful coexistence between these two nations and ethnic groups.

\section{History of Serbo-Croatian tensions}

Between the 14th and 17th century the Ottoman expansion in the Balkans pushed many Serbs to cohabit with Croats. This cohabitation occurred in a buffer zone named "the military confines". This zone lasted until 1878, the same year Serbia gained independence. During this period, although the two peoples lived together, they assimilated very little [Garde 1999]. During the 19th century, Croats and Serbs started to realize that they weren't very different and considered the potential option of living under the same state. The Illyrian movement, quickly renamed Yugoslav, emerged. The main idea is that Croats and Serbs would mutually benefit from a common political construction. The Croats would be able to extricate themselves from the Austrian yoke and the Serbs would become part of a more powerful state, more capable of resisting its neighbors.

The supporters of the movement in both countries then operated a cultural rapprochement in particular thanks to linguistic reforms [Garde 1999]. In 1918, Croatia lost the First World War to the victorious Serbia which had suffered many losses. The twostates decided to concretize this Yugoslav project and unite in the "Kingdom of Serbs,Croats and Slovenes" under the monarchy of the Serbian king Karageorgevich. Very quickly, the Croats considered themselves disadvantaged by the new political construction. They demanded more decentralization in form of federalization. The Serbian political elite opposed this because it wanted to create a united Yugoslav civic identity, which could only be achieved by forming a unitary state. They legitimized the concentration of political power in Belgrade through appealing to numerous Serbian sacrifices during the First World War, which left a deep mark on their memories. Many dissenting voices were raised. Violent Albanian and Bulgarian independence movements were harshly repressed. The Communist Party was banned. The Croatian democrat and pacifist Stjepan Radic was shot dead by a member of the Serbian Radical People's Party in the middle of parliament on 20th of June 1928. This murder provoked a shocked the Croatian population and aggravated tensions between the Croats and the Serbian leaders. At 
this moment, the government retained power by using repression and corruption. In 1934, King Alexander Karageorgevich was assassinated as the result of a conspiracy between Croatian fascists (the Ustasha) and Bulgarian terrorists.

The regency was taken over by Prince Paul who had too littletime to change the course of his predecessor, although the Croatian Banovina was formed prior to the outbreak of the war, which meant that Yugoslavia was set on the course of federalization and the construction of Yugoslavian civic identity was left behind in favor of ethnic identities [Garde 1999]. The Second World War was the first extensive trauma that deeply deteriorated relations between Serbs and Croats. The Kingdom of Yugoslavia was quickly defeated by the Germans. While Serbia saw the establishment of a government by collaboration of circumstance, the Independent State of Croatia was proclaimed by the Ustasha. It was led by Ante Pavelic who fully committed to collaboration with the Germans. At this moment, many Croats perceived the Germans as liberators of the Serbian yoke. Similar to other Nazi-occupied countries, a policy of discrimination against Jews and Gypsies was implemented. Nevertheless, the Ustasha decided to persecute the Serbs as well. The Cyrillic alphabet was banned and Serbs were no longer allowed in the army, to be politically involved or have certain professions. Numerous massacres were perpetrated by Ustasha units which rounded up hundreds of Serbian villages and executed the inhabitants after subjecting them to all sorts of humiliations and torture. Death camps were set up, such as the one in Jasenovac, even before the Nazi "final solution" appeared [Garde 1999].

Two groups of resistance fighters emerged, the Chetniks formally led by colonel, and later general, Dragoljub Mihailovic and the Partisans led by Josip Broz alias Tito. The Chetniks were actually a decentralized movement, at the top a Yugoslav nationalist group that actually supported the idea of a Yugoslav civic identity, and at the bottom mostly a Serbian nationalist movement. While the top brass of the Chetniks did not approve of violence against the Croatian and Bosniak population, the bottom ranks that mostly operated independently responded to the massacres orchestrated by the Ustasha on Serbs with other massacres on Croatian and Bosniak populations. The Partisans, who were a multi-ethnic communist group, opposed both the Ustasha and Chetniks, but they were organized along class divisions and did not aspire to democratic political values. As Mihailovic gained Western support, the Chetniks were no longer actively fighting the Germans but only the Partisans. In 1944, when the British understood this, they stopped supporting the Chetniks and assisted Tito, who had about 300,000 fighters in his ranks. At the end of the war Tito's fighters forced the prisoners (who had originally surrendered to the British in Bleiburg) to go on a long death march through all of Yugoslavia. According to Tito's former lieutenant, Djilas, between 20,000 and 30,000 people died. The burden of the war was very heavy in the Balkans. The Jews were almost entirely exterminated and the conservative estimate of Serb victims counted approximately 315,000 dead (civilians and combatants) on the territory of the Independent State of Croatia [Kocovic 1985]. 
Tito's Partisans came to power in 1945 and revolutionized Yugoslavia. The increase in tensions between Serbs and non-Serbs was blamed on the political failure of the interwar period [Wachtel, Bennett 2009]. The old power was also accused of having tried to "Serbianize" the country [Wachtel, Bennett 2009]. The new Yugoslavia was organized as a federal state led by the Communist Party. It recognized six nations (Serbs, Croats, Slovenes, Macedonians, Montenegrins, and in 1968, Muslims) in six republics (Croatia, Slovenia, Montenegro, Macedonia, Bosnia-Herzegovina, Serbia). Nevertheless, the construction of a Yugoslav civic identity was a failure. At each political crisis, instead of uniting in difficulty to overcome their problems, citizens divided and withdrew into their respective ethnic communities [Wachtel, Bennett 2009]. Andrew Wachtel and Christopher Bennett explain this withdrawal by the nature of the social contract that bound citizens to thestate: the state was constituted more on the basis of a people-state relationship than an individual-state one, which explains the failure to construct a civic identity through the lack of democratic political institutions. "In this context, personal and cultural realization wasconceived as possible only within a national envelope. To be sure, the envelopeswere more numerous than before, but the country was still oriented toward communitarian rather than individual values." Gradually, the federal structures of Yugoslavia weakened in favor of the ethnic republics, which began to behave as independent entities. In 1967, Croatia experienced the beginning of a nationalist cultural movement, the "Croatian Spring". In 1970, a conference of the movement was held and it was decided that it was necessary to reduce the number of Serbian authors in order to give a bigger place to Croatian national writers. The movement was repressed by the communist federal authorities in 1971 with the arrest of many intellectuals. This repression was perceived by the Croats as unjust and contributed to "delegitimize the Partisan legacy on which the postwar Yugoslav state was based" [Wachtel, Bennett 2009].

The death of Tito in 1980 aggravated the political and economic difficulties that Yugoslavia was already facing. The failure of the Yugoslav civic identity and state project is also characterized in the 1981 census, since only $5.4 \%$ of the population chose to define themselves as Yugoslavs. Nevertheless, it should be noted that this figure was increasing. Since, only 273,000 people (3.1\%) declared themselves Yugoslavs in the 1971 census [Garde 1999]. The Communist Party faced a new challenge: to maintain popular support for the Yugoslav project at a time when the desire for a democratic society was emerging. To obtain this support, the younger communist leaders in the ethnic republics therefore turned to nationalism [Mujanovic 2018]. A Serbian nationalist discourse then developed around sacrifice andheroism, with some accounts going as far as the battle of Kosovo in 1389 [Ramet 2007]. Some Serbs then put forward the sacrifices they made during the Second World War and claimed that they had a disadvantaged position in Tito's Yugoslavia. They also accused the Croats of having orchestrated the massacre of hundreds of thousands of Serbs duringthe collaboration with the Nazis. On the other hand, some Croats considered the "colonization" of the Krajina 
(by the Serbs) as illegitimate even though it dated back to the time of the military confines I the $17^{\text {th }}$ century. They also downplayed, or even denied, the sacrifices that the Serbian people had made in earlier periods, and blamed the Serbs for having used the Kingdom of Yugoslavia to satisfy their hegemonic ambitions in the region. They minimized their collaboration with the Nazis and in response, pointed to the atrocities committed by the Chetniks.

Thus, each side criticized the previous exactions of the others. It should be noted that at this time the Serbs were the majority in the country since they constituted $36 \%$ of the population while the Croats were only the second nation in terms of population with $19.7 \%$ according to the census of 1981 [Garde 1999]. While Tito, often by force, silenced nationalist and particularist movements - Milosevic, then head of the Belgrade section of the Communist Party in 1984,encouraged them. First of all, he used the situation of the Serbs in Kosovo to arouse popular enthusiasm. This allowed him to condition the masses and to impose profound transformations on Serbia and several other federal entities. After having purged the Serbian Communist League [Wachtel, Bennett 2009] and getting a grip on the media [Stokes 2009], he became the President of the Central Committee of the League of Communists of Serbia. The 14th Congress of the Yugoslav Communist League held January 20-22 1990. This was a crucial step in the fall of Yugoslavia as Milosevic's actions were oriented towards the restoration of a centralized Yugoslavia, which other ethnicities were not willing to accept no matter what. It is worth noting that Milosevic had aspirations to retain Yugoslavia as a state, but he did not have any intentions of developing democratic institutions, which meant that the project of the Yugoslav civic identity was not a part of his agenda.

Slobodan Milosevic arrived with confidence at the Congress since he already controlled four of the eight administrative entities of the republics. He only needed to convince one republic to impose his policies on the others. Slovenia and Croatia continued to strongly oppose his policy. Both countries no longer wished to contribute to the development of the southern Yugoslavian republics and claimed a certain autonomy in order to benefit from their national income, they also, at this point, didn't even try to hide their separatist aspirations. On the other side, Milosevic and his numerous supporters maintained the need to recentralize Yugoslavia for its proper functioning. The parties were unable to reach an agreement at the Congress. Croatia and Slovenia left the Congress prematurely ${ }^{1}$.

Parliamentary elections in May 1990 in Croatia brought the Croatian nationalist party Hrvatska Demokratska Zajednica (HDZ) to power as a result of rising interethnic tensions and distrust of Yugoslav institutions. The few parliamentarians elected from the Srpska demokratska stranka movement were soon after threatened physically and verbally during a session of Parliament in Zagreb. The Croats criticized, among other things, anoverrepresentation of Serbs and Montenegrins in the police $\&$ army and moregenerally in the institutions. Shortly afterwards, Franjo Tudjman of the HDZ was elected President of the Yugoslav Republic of Croatia.

\footnotetext{
${ }^{1}$ BBC, Yougoslavie "Suicide d'une nation européenne", first episod, 1995, published on the 25.04.2013. URL: https://www.youtube.com/watch?v=I1oZc9oLNFc (accessed: 20.09.2021).
} 
Croats feared that a "state forall Serbs" would be created, a project promoted by some politicians such as Vojislav Seselj of the Serbian Radical Party. As a result, many Serbs were fired, especially in security-related jobs. The latter were represented in large numbers compared to the Croats since they constituted 57,1\% of the Yugoslav officers whereas they were only 36,3\% in Yugoslavia [Bjelajac, Žunec 2009]. The Serbs in Croatia reacted by feeling threatened by whatthey saw as a resurgence of an anti-Serb government - which they did not hesitate to compare to the fascist Ustasha regime of World War II [Stokes 2009]. As Gale Stokes explains, "At least some members of almost every ethnic group in the former Yugoslavia suddenly became frightened that they would be permanently relegated to the statusof minority, outvoted in elections, pushed out of jobs, and otherwise discriminated against" [Stokes 2009]. It was in this context that the Serbs of Krajina seceded on April 1, 1991. Fighting quickly broke out between Croatian forces and Serbian paramilitaries.

The Jugoslovenska narodna armija (JNA) intervened several times in favour of the Serbs. On June 25, 1991, Croatia and Slovenia both declared their independence. A short war of a few days broke out in Slovenia. As Milosevic was ready to let this republic leave Yugoslavia, the conflict ended quickly. Meanwhile, theconflict in Croatia escalated. Joint JNA operations with Serbian paramilitary forces were conducted in Slavonia, Dalmatia and central Croatia. The city of Vukovar, inhabited both by Serbs and Croats became a central focus of the civil war and fell on 19 November 1991. One of the first atrocities of the conflict was committed that day when the 260 people in the hospital, mainly wounded and medical personnel, were executed in a field by Serbian paramilitaries with the complicity of the JNA ${ }^{2}$.

At the beginning of the war, the Croatian forces wereat a serious disadvantage, they were under-equipped, poorly structured and poorly coordinated in the face of the Serbian militias and the JNA ${ }^{3}$. For Croatia, the Serbian offensive resulted in the gradual loss of a third of its one hundred and fifteen municipalities [Garde 1999]. After the military operation in Slavonia, the paramilitary forces and the JNA began the expulsion of non-Serbs from the conquered areas. At the same time, the Croat side also engaged in ethnic cleansing of its territory from the Serbs. International observers begin to raise the notion of ethnic cleansing, which the UN defines as practices aimed at "making an area ethnically homogeneous by using force or intimidation to displace a particular ethnic or religious group from an identified area" 4 . On December 23, 1991, Germany and France recognized Croatia's independence against the advice of the Badinter Commission. Two weeks later, a

\footnotetext{
${ }^{2}$ Central Intelligence Agency, Balkan Battlegrounds: A Military History of the Yugoslav Conflict, 1990-1995. Washington: CIA Office of Public Affairs. 2002. URL: https://www.loc.gov/item/ 2010588135/ (accessed: 20.09.2021).

${ }^{3}$ Ibid.

${ }^{4}$ United Nations Security Council, Final Report of the United Nations Commission of Experts Established Pursuant to SCR 780 (1992), S/1994/674, 27 May 1994; Annex IV: The Policy of Ethnic Cleansing, S/1994/674/Add. 2 (Vol. I), 28 December 1994. URL: https://www.icty.org/x/file/ About/OTP/un_commission_of_experts_report1994_en.pdf (accessed: 20.09.2021).
} 
cease-fire agreement was signed under American pressure. The Vance Plan, which provided for the dispatch of 14,000 UN peacekeepers, was put in place in February. The soldiers of the United Nations Protection Force (UNPROFOR) were then deployed in Croatia in the Serb majority regions [Calic 2009].

In the meantime, the conflict had spread to Bosnia, where the distribution of Bosniaks, Croats and Serbs was very scattered. As the war progressed, the Croats allied themselves with the Bosniaks in order to support an independent Bosnian state "which they considered the best guarantee for the survival of their communities" [Tanner 2001]. The Serbs also refused to be a minority in Bosnia. They seized many towns including the outskirts of Sarajevo, which was to undergo a 43-month blockade while most of the Serb inhabitants of the city were expelled. On 7 April 1992, the Republika Srpska (RS) officially declared its independence. From 1992 to 1994, fighting continued in Bosnia and Croatia. It was not until December 1994 that a real turnaround in the war occurred. Operation Flash allowed the Croats to reconquer the whole of Slavonia and to inflict a major defeat in less than a week. As a result, Serbian forces were demoralized and the ensuing fighting turned against them. On August 2, 1995, Croatian forces recovered the entire Krajina during Operation Storm. During these offensives, numerous acts of violence were committed against civilian Serb population in retaliation for what the Croats considered retribution for the crimes they had previously suffered. Most Serbs from Croatia preferred to flee the country for fear of persecution [Tanner 2001].

The war ended on December 14, 1995 with the signing of the Dayton Agreement. Croatia recovered its entire territory while Bosnia was divided into two entities, on one side the Muslim-Croat Federation and on the other the Republika Srpska. In Croatia, the conflict cost the lives of 15,000 Croats and 7,000 Serbs, including 400 civilians on both sides [Mitrović 2003]. In total, the Hague tribunal estimated the number of refugees to be around 150-200,000. The Croatian Helsinki Committee for Human Rights estimated that 22,000 houses were burned [Calic 2009]. After the war, although political agreements were signed for the reintegration of Serbs, especially in Slavonia, the role of Serbs in Croatian society was drastically reduced. In Bosnia, where ethnic cleansings were more frequent, the number of deaths was substantial. According to Tokaca's research which was confirmed by the Demographic Unit of the ICTY about 100.000 people died [Calic 2009]. There were "64,036 Bosniaks, 24,905 Serbs, 7,788 and 478 others or unknown" [Calic 2009]. According to the Human Rights Institute of the University of Chicago, approximately 1,100 cases of rape were recorded in 162 detention facilities [Mitrović 2003]. The Camp Inmates Association estimated that approximately 200,000 civilians were imprisoned in $650 \mathrm{camps}^{5}$. Among them, 30,000 were killed and 25,000 women were raped. More generally, the SerboCroat-Bosnian conflict caused the uprooting of more than 2 million people

\footnotetext{
${ }^{5}$ Final Report of the United Nations Commission of Experts, Annex IX: Rape and Sexual Assault, S/1994/674/Add.2 (Vol. V), 28 December 1994, p. 7, para. 4. URL: http://www.law.depaul.edu/ institutes_centers/ihrli/_downloads/ANNEX_IX.pdf(accessed: 20.09.2021).
} 
according to the United Nations High Commissioner for Refugees. Trials will take place much later targeting Serb, Bosnian and Croat politicians and military officers.

\section{Evaluation of current tensions between young people under $\mathbf{3 5}$ years old in Croatia and Serbia}

First, the collecting of witnesses confirmed the existence of current tensions. They expressed positive or negative experiences they have been through. Adriane, a French teacher, saw her entire class mocking a pupil, who was talking about her vacation at her grandmother's in Serbia. Miroslav, a 29-year-old FrenchSerbian, was confronted by two men in Zagreb. They told him that he was "talking like a moron" and that he should not "speak Serbian here". Bruna, a 23-year-old Croatian, explains that she regularly sees videos on social networks of Serbs burning Croatian flags. She also says that there are almost systematic clashes between fans of Croatian and Serbian teams in sports matches. However, it should be noted that such discrimination is not systematic, as Serbian citizens have also had positive experiences. Marko, a 34-year-old Serbian, admitted that he had great encounters in Zadar even though he was afraid of encountering difficulties if he were to speak Serbian. The parents of Lea, a 20-year-old Serbian, were worried about potential discrimination four years ago when they went to Croatia for the first time. Now, they go every summer to the Adriatic coast. It is difficult to quantify the number of "bad experiences" of Serbs in Croatia. It is undeniable that they exist and contribute to spreading the idea that it can be dangerous for a Serb to come to Croatia. Aleksandar, 24-year-old Serbian would like to visit a friend in Croatia but is afraid of being beaten up in the street. Irena, 22 years old, Serbian, is afraid that her car will be vandalized or burned while she dreams of visiting the Croatian beaches. Jelena, a 23 years old Serbian, heard that Serbs are not welcome but still wants to come. Nina, a 22-year-old Serbian, would go to Croatia if "people didn't become unpleasant as soon as you address them in Serbian". All these testimonies show that there are tensions between Serbian and Croatian civil society. It is quite easy to find people of Serbian nationality who had problems in Croatia and much more difficult to find Croats who had problems in Serbia. There are several reasons for this. First of all, Croatia being in the European Union, Croats tend to go to European countries rather than to Serbia. Second, the proportion of Croats in Serbia is lower than the proportion of Serbs in Croatia. There were 57,900 Croats in Serbia in 2011 which represented $0.8 \%$ of the population $^{6}$ while there were 186,633 Serbs in Croatia, which represented 4.4\% of the population ${ }^{7}$. Since the war took place on Croatian territory and not on Serbian territory, Croats were more impacted by the events than Serbs.

\footnotetext{
${ }^{6}$ Archives of the Republic of Serbia. URL: https://archive.is/20130416163334/http://webrzs.stat.gov.rs/ WebSite/Public/ReportResultView.aspx?rptId=1216 (accessed: 20.09.2021).

${ }^{7}$ Croatian Central Bureau of Statistics. URL: https://www.dzs.hr/Eng/censuses/census2011/results/ htm/E01_01_04/e01_01_04_RH.html (accessed: 20.09.2021).
} 
In order to evaluate the quality of current relations between Croats and Serbs, fieldwork was carried out for 5 months in Croatia and 3 months in Serbia. During the fieldwork, a 13-question survey (see Table) was distributed among two groups, one Serbian and one Croatian, consisting of people under the age of 35.

This survey targeted youth. As youth is not an objective period, it is difficult to defineit. It starts after adolescence, when the individual is growing and developing, and ends with the passage to adulthood defined "by the conquest of a place, professional and social, and the acceptance of the responsibilities that go with it"8. In France, the National Institute of Statistics and Economic Studies defines youth as 15-29 years old ${ }^{9}$. However, this delimitation is different in each country. In the Balkans, young people tend to need more time to definitively emancipate themselves from family support. They study and stay with their parents longer than in Western Europe ${ }^{10}$.

Table

Questionary

\begin{tabular}{|c|c|c|}
\hline No. & Questions & Answers \\
\hline 1 & Are you? & A man / A woman \\
\hline 2 & What is your nationality? & Croatian / Serbian \\
\hline 3 & How old are you? & $\begin{array}{l}-18 \text { y.o. }-18-25 \text { y.o. }-26-35 \text { у.о. } \\
-+36 \text { y.o. }\end{array}$ \\
\hline 4 & What is your socio-professional category? & $\begin{array}{l}\text { - Student - High school graduate } \\
\text { - University graduate - Unemployed } \\
\text { - Retired }\end{array}$ \\
\hline 5 & From what city do you come from? & ------- \\
\hline 6 & In what city do you live? & ------- \\
\hline 7 & $\begin{array}{l}\text { Do you have Serbian/Croatian roots or } \\
\text { Serbian/Croatian family in Serbia/Croatia? }\end{array}$ & Yes / No \\
\hline 8 & $\begin{array}{l}\text { Do you agree with this affirmation: } \\
\text { "From the 1991-1995 war, tensions still occur } \\
\text { between Croats and Serbs" }\end{array}$ & $\begin{array}{l}\text { - Totally agree - Rather agree - Rather } \\
\text { disagree - Disagree - Don't know }\end{array}$ \\
\hline 9 & $\begin{array}{l}\text { Do you think reconciliation between Croatia } \\
\text { and Serbia is possible? }\end{array}$ & Yes / No \\
\hline 10 & Why? & ------ \\
\hline 11 & $\begin{array}{l}\text { Do you wish for reconciliation between Croatia } \\
\text { and Serbia? }\end{array}$ & Yes / No \\
\hline 12 & Why? & ------- \\
\hline
\end{tabular}

Source: made by the authors.

\footnotetext{
${ }^{8}$ CREDOC, “Today's youth: what society for tomorrow?", Cahier de recherche $\mathrm{N}^{\circ} \mathrm{C} 292$, December 2012. URL: https://www.credoc.fr/publications/les-jeunes-daujourdhui-quelle-societe-pour-demain (accessed: 20.09.2021).

${ }^{9}$ CREDOC, “Today's youth: what society for tomorrow?", Cahier de recherche $\mathrm{N}^{\circ} \mathrm{C} 292$, December 2012. URL: https://www.credoc.fr/publications/les-jeunes-daujourdhui-quelle-societe-pour-demain (accessed: 20.09.2021).

${ }^{10}$ Ibid.
} 
Therefore, it is possible to match this period to the age range 18-35, used in the field survey.

Youth is a key element of the population as it represents a force for change in society. This $18-35$ generation is relevant to study because it will become the part of the working population in society that will be in charge of making decisions in both the public and private sectors in the next 25 years. A total of 104 people under the age of 35 responded to the survey.

In Croatia, the survey shows that there is undeniable tension between Serbs and Croats, with $90.8 \%$ of respondents agreeing on this point (Fig. 1).

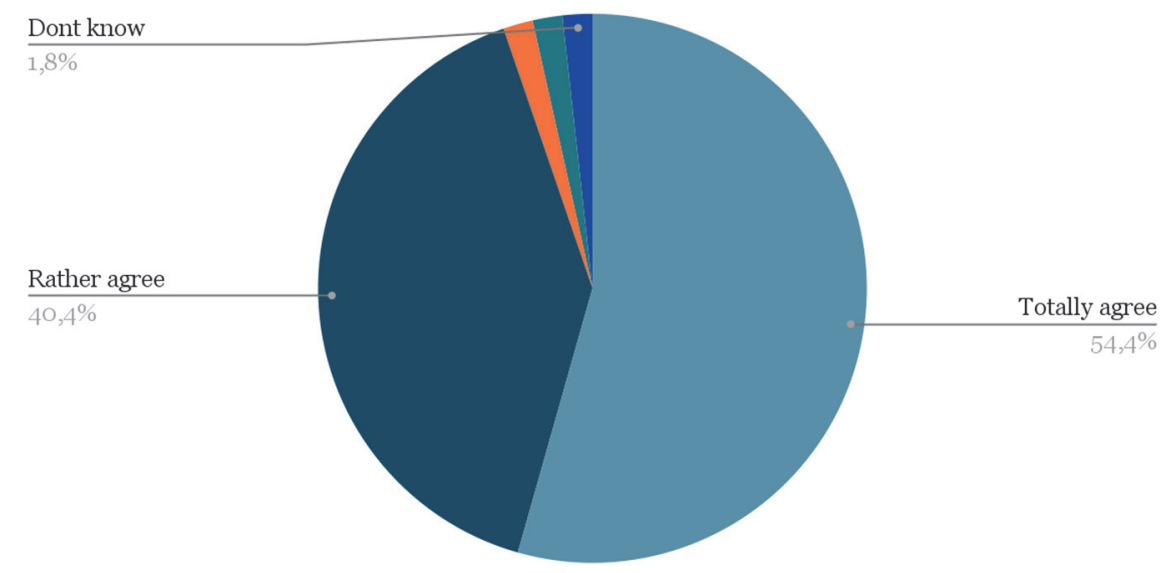

Fig. 1. Croatian answers on Question 8 - Do you agree with the following sentence: "Since the end of the war in 1995, tensions still exist between Serbs and Croats?" Source: made by the authors.

When asked about the possibility of reconciliation, it appears that all respondents with family in Serbia or with Serbian origins (12\%) answered that reconciliation was possible. It should be noted that a quarter $(24.6 \%)$ of the respondents believe that reconciliation is not possible. The reasons given were mainly the consequences of thewar $(66.7 \%)$ and the presence of interethnic hatred $(33.3 \%)$. Those who believe that reconciliation is possible mainly cite the need to move on and move forward at $50 \%$. However, $20.9 \%$ conditioned their positive response on a need for change (Fig. 2).

The region of origin of the people surveyed also appears to be an important criterion in the choice of response. Indeed, people from regions strongly affected by the war are more likely to suggest that reconciliation is not possible. This is the case for people from Slavonia, where 9 out of 18 people think that reconciliation is not possible. People from regions less affected by the war tend to think that reconciliation is possible. In central Croatia, 18 out of 19 people consider it possible. In contrast, it appears that people from Bosnia are more likely to believe that reconciliation is possible (4 out of 5). It is interesting to note that the vast majority of respondents want reconciliation $(94.9 \%)$. It should be noted that among the $5.1 \%$ who are opposed to it, the majority also come from areas heavily affected by the war. 


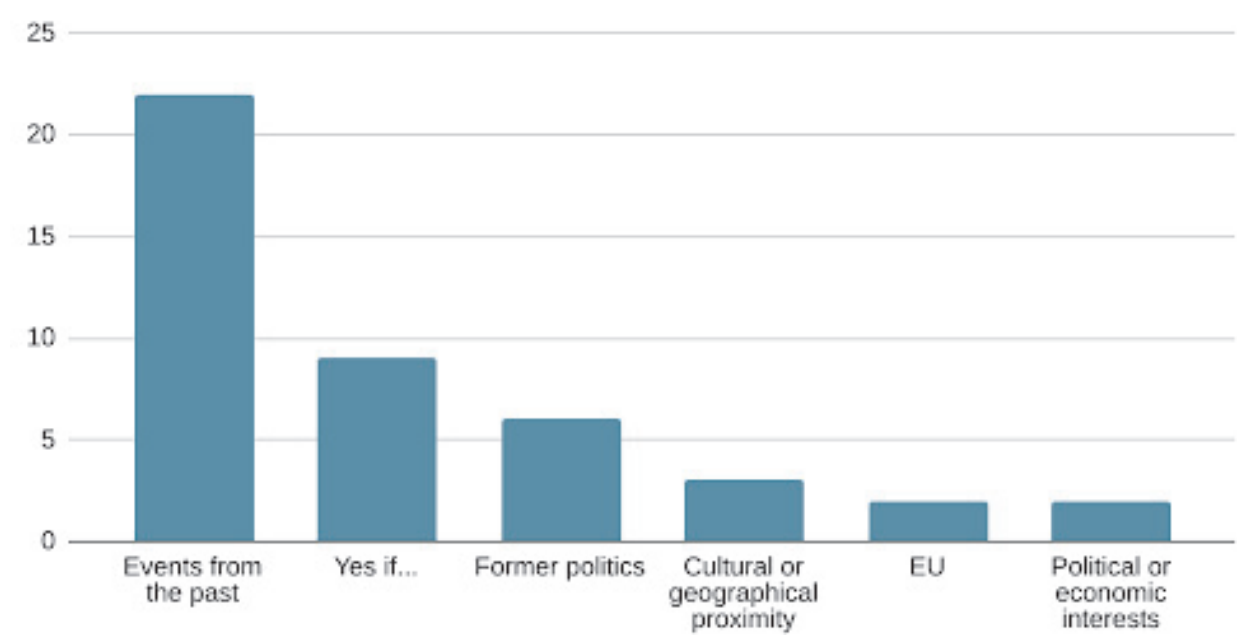

Fig. 2. Croatian answers to the question "Why is reconciliation possible between Croatia and Serbia?" Source: made by the authors.

In Serbia, the survey shows that there are tensions between Serbs and Croats, with $80 \%$ of respondents agreeing on this point (Fig. 3).

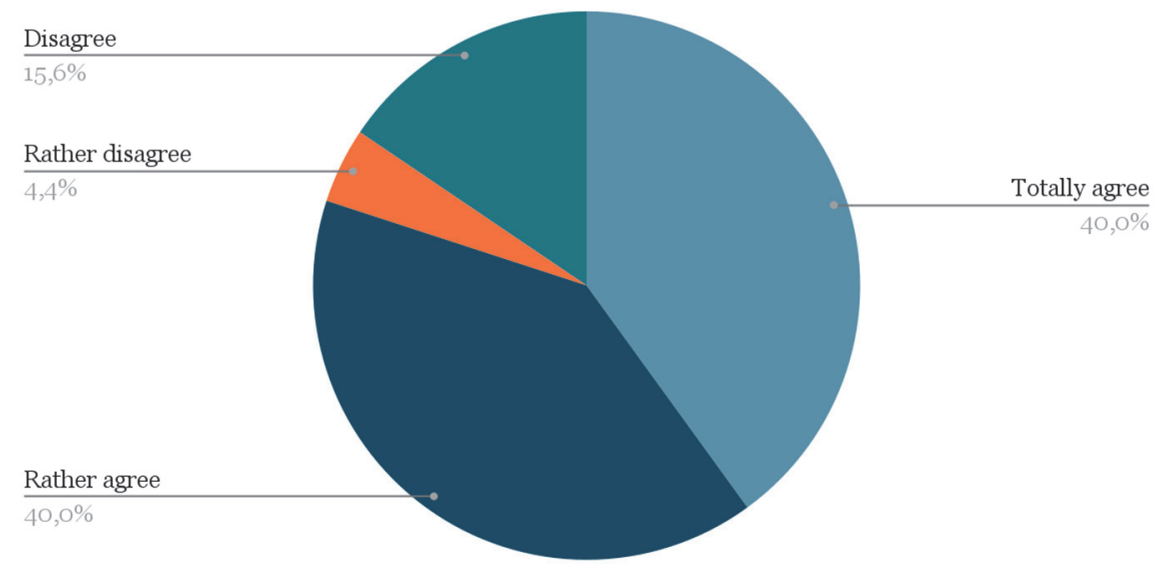

Fig. 3. Serbian answers on Question 8 - Do you agree with the following sentence: "Since the end of the war in 1995, tensions still exist between Serbs and Croats?" Source: made by the authors.

However, $15.6 \%$ of the respondents did not know how to answer this question. When asked about the possibility of reconciliation (Fig. 4), 66.7\% of Serbs believe it is possible. It should be noted that people aged 26-35 are more pessimistic (60\%) about the possibility of reconciliation than people aged 18-25 (25.7\%). Also, having family in Croatia or Croatian origins does not appear to be a major criterion in this decision. However, one third of the respondents $(33.3 \%)$ believe that reconciliation between Croatia and Serbia is not possible. The reasons given were mainly the consequences of the war (69.2\%) and the presence of interethnic hatred $(23.1 \%)$. Those who believe that reconciliation is possible, mainly cite the need to 
move on and move forward at 30.4\%. However, $21.7 \%$ of Serbians still condition their positive response on a need for change.

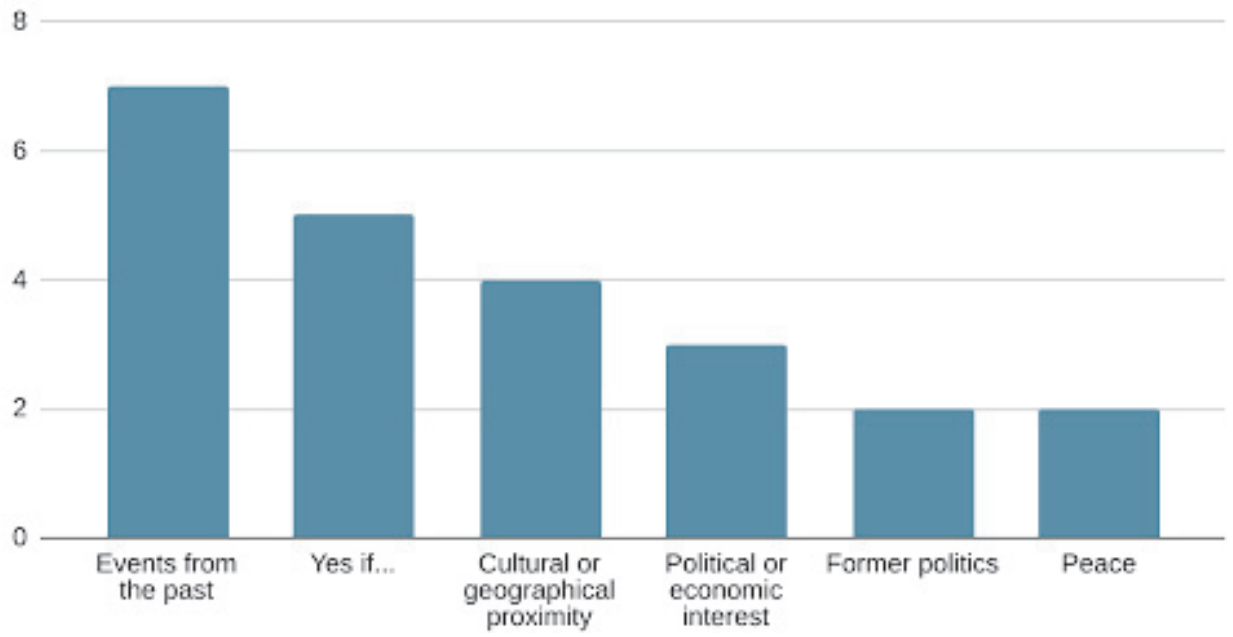

Fig. 4. Serbian answers to the question "Why is reconciliation possible between Croatia and Serbia?" Source: made by the authors.

It is interesting to note that the vast majority of the people surveyed, want reconciliation $(97.8 \%)$. Since only one person is opposed, it seems difficult to determine a general trend.

The survey of persons under 35 years old in Croatia and Serbia yielded several findings. First, the share of people with family or origins in Serbia for Croats, and Croatia for Serbs is similar; $21.1 \%$ of Croats have family in Serbia or Serbian origins and $17.8 \%$ of Serbs have family in Croatia or Croatian origins.

When it comes to the existence of tensions between the two peoples, Serbs are less categorical than Croats. Only 40\% "Strongly agree" among Serbs while 54.4\% agree among Croats. Also, while only one person answered "don't know" in Croatia, 15.6\% answered "don't know" in Serbia. This can probably be explained by the fact that the war took place on Croatian territory and not on Serbian territory. The lack of exchanges between the two countries could be an explanation for the lack of knowledge of the situation among young Serbs.

When reconciliation is mentioned, Croats are more likely to consider it than Serbs. About $75 \%$ of Croats think it is possible, compared to $66.6 \%$ of Serbs. In Croatia, having family in Serbia or having Serbian origins contributes very strongly to thinking that reconciliation is possible. $100 \%$ of Croats with family in Serbia or Serbian origins believe it is possible. In Serbia, on the other hand, this tendency is not true, since out of the 8 persons who have family in Croatia or Croatian origins, three believe $(37,5 \%)$ that reconciliation is not possible. In Serbia, people aged 26-35 are more pessimistic about the possibility of reconciliation, whereas in Croatia, age does not appear to be a determining factor in the possibility of reconciliation.

In both groups, people who believe that reconciliation between Croatia and Serbia is possible mention the same arguments. The importance of forgetting the 
traumatic events of the past is the first reason in both surveys (50\% of responses in Croatia and $30.4 \%$ in Serbia). A conditional affirmative answer is also given in equal proportions in both surveys $(20.5 \%$ in Croatia and $21.7 \%$ in Serbia). Those who believe that reconciliation is not possible also mention the same arguments and in similar percentages. $66.7 \%$ of Croatian respondents and $69.2 \%$ of Serbs attribute the impossibility of reconciliation to the consequences of the war. While Croats attribute this solely to the events of the 1991-1995 war, Serbs attribute it to both the 1991 war and the Second World War. Both surveys also show that both Croats $(33.3 \%)$ and Serbs $(23.1 \%)$ believe that the presence of interethnic hatred does not allow for this reconciliation.

Therefore, the study concludes that an overwhelming majority wants reconciliation in both countries $(94.9 \%$ in Croatia and $97.8 \%$ in Serbia) (Fig. 5). Among Serbs and Croats who want reconciliation, the same reasons are given but in a different priority order.

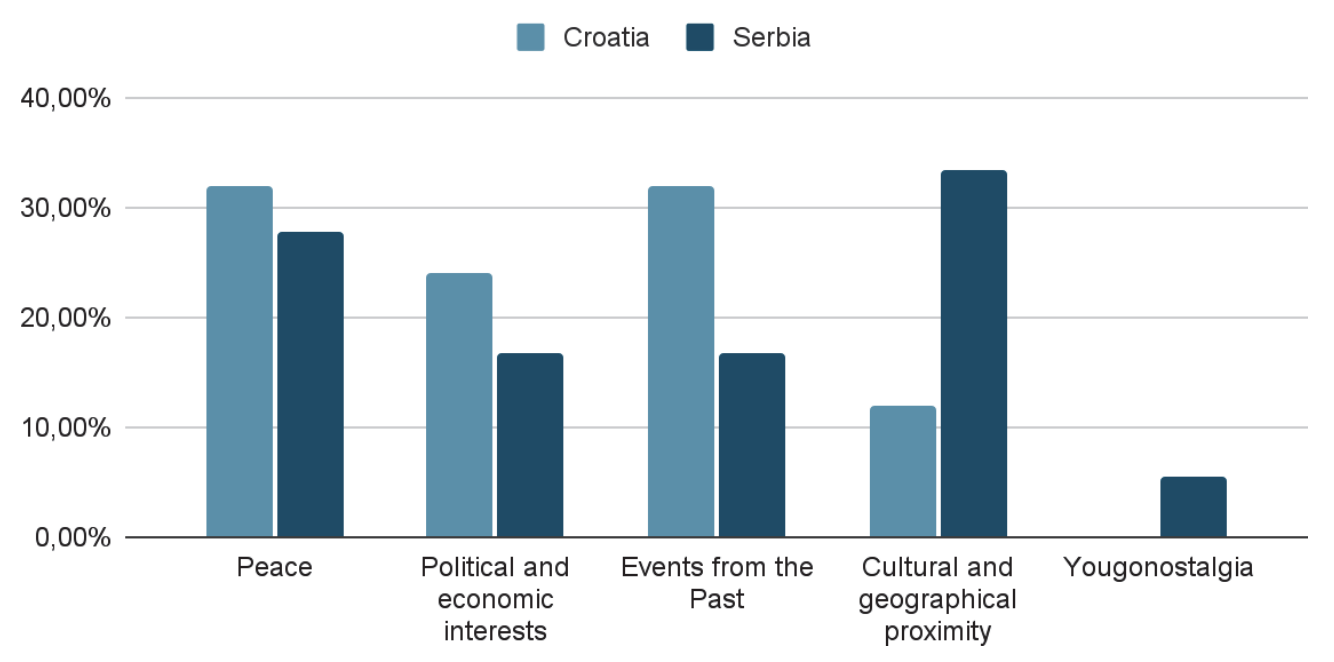

Fig. 5. Croatian and Serbian answers to the question "Why do you wish forreconciliation between Croatia and Serbia?" Source: made by the authors.

Cultural and geographical proximity is the reason that should allow this reconciliation for $12.5 \%$ of Croats and $33.3 \%$ of Serbs. It is interesting to note here that Serbs feel closer to Croats than the Croats do to Serbs. Both groups give almost equal importance to living in peace (32\% in Croatia and $27.8 \%$ in Serbia). However, Croats (24\%) place more importance on economic and political interests in reconciliation than do Serbs (16.7\%). The need to move beyond the events of the past, not to harbor grudges and to make room for the younger generation is much more important in Croatia (32\%) than in Serbia (16,7\%). It is interesting to note that "Yugo-nostalgia" is mentioned in 5.6\% of the responses in Serbia, while it is not mentioned in Croatia. Among Croats and Serbs who do not want reconciliation, the same reasons are given, namely the impossibility of forgiving the atrocity of past events. 


\section{Conclusion}

The appearance of real tensions between Serbs and Croats corresponds to the first attempt to build a common political project, the Kingdom of Slovenes, Croats and Serbs in 1918 that had the aims of creating a common civic identity for both Serbs and Croats. The first real trauma occurred during the Second World War when the Ustasha brutally and systematically persecuted the Serbs in the entire territory of the Independent State of Croatia. A return to calm was imposed by the arrival to power of Tito, even if he failed at the end to build a true Yugoslav identity because the communist regime was not oriented towards democracy and civil society. As the State had addressed itself directly to the communities and not to the individuals, it created a fertile ground for community with drawal and nationalist desires. Meanwhile, Yugoslavia was going through political and economic difficulties in the 1980s. The republics no longer shared the same goals and political tensions began to develop in civil society. Milosevic was the first to use these tensions for his personal political gain and then it was the turn of Tudjman and Izetbegovic. In the spring of 1991, war broke out and ultranationalist militias emerged on both sides, causing numerous atrocities. The 1991-1995 war was the second trauma in relations between Serbs and Croats. People who were once neighbors, cousins, friends killed each other. Thousands of people were uprooted, persecuted, killed for their community affiliation.

Today, relations between Croatian and Serbian civil societies remain strained and civic identity isn't the goal of both countries (a united civic identity is completely unattainable without a common state). Those who agreed to share their testimonies with the authors as researchers witnessed the existence of non-systematic presence of discrimination of Serbs in Croatia and Croats in Serbia. These discriminations are always directly linked to the nationality of the person or to the language (dialect) he or she speaks. It strongly influences travel plans between the two civil societies and slows down cultural exchange. The results of a survey of people under 35 years old in Croatian and Serbian civil society shed more light on these tensions. A large majority in Croatia and Serbia agree on the existence of tensions between the two peoples. Reconciliation seems possible for three quarters of Croats and two thirds of Serbs surveyed. This reconciliation seems necessary since there are still links between the two peoples, as about one in five people have family ties in the other country. Those who do not believe that reconciliation is possible cite the consequences of the war as the main obstacle, followed by the presence of interethnic hatred as the second reason. Thus, the survey demonstrated the existence of a genuine desire for reconciliation between civil societies.

Therefore, even if relations between Serbs and Croats are still complicated 25 years after the Dayton Peace Agreement, reconciliation does not seem impossible either. The new generations that have not experienced the war are more in favor of reconciliation and the majority of them consider it possible. Since civil societies should not hindera process of improving relations between the two countries, the success of this reconciliation will therefore depend on political relations between Croatia and Serbia and especially on the institutional choice of these two states. Unfortunately, it is becoming more and more evident that both the political elites 
of Croatia and Serbia are disinterested in opting for civic identity as opposed to ethnic policies they currently adhere to. Meanwhile, the redefinition of the European integration process of the Western Balkans and Serbia's efforts to apply for EU membership suggest that relations between the two countries will improve in the coming years.

Received / Поступила в редакцию: 20.09.2021

Accepted / Принята к публикации: 01.10.2021

\section{References}

Beljo, A. (1985). Yugoslavia, genocide, a documental analyses. Sudbury (Conn.), Northern Tribune, 49-65.

Bjelajac, M., \& Žunec, O. (2009). The War in Croatia, 1991-1995. In C. Ingrao \& T.A. Emmert (Eds.), Confronting the Yugoslav controversies: A scholars' initiative (pp. 231-270). Central European Studies Series Purdue University Press.

Calic, M. (2009). Ethnic cleansing and war crimes, 1991-1995. C. Ingrao \& T.A. Emmert (Eds.), Confronting the Yugoslav controversies: A scholars' initiative (pp. 115-151). Central European Studies Series Purdue University Press.

Garde, P. (1999). Life and Death of Yugoslavia. Fayard. (In French).

Hobsbawm, E. (1993). What is an ethnic conflict? Actes de la recherche en sciences sociales, 100, 51-57. (In French).

Jackson, R.L., \& Hogg, M.A. (2010). Encyclopedia of identity. SAGE Publications.

Kocovic, B. (1985). Victims of World War II in Yugoslavia (pp. 31-41). Biblioteka Nase delo, Londres, Sarajevo. (In Serbian).

Mitrović, M. (2003). Ethnic cleansing of Serbs from Zagreb 1992-1994 - according to oral history. Tokovi istorije, (3-4), 89-98. (In Serbian).

Mujanovic, J. (2018). Hunger and fury: The crisis of democracy in the Balkans. Oxford University Press. Pirotte, G. (2018). Definition of civil society. Paris: La Découverte, Repères. (In French).

Ramet, S. (2007). The Dissolution of Yugoslavia: Competing Narratives of Resentment and Blame. Südosteuropa, 55, 30-40.

Stokes, G. (2009). Independence and the fate of minorities, 1991-1992. In C. Ingrao \& T.A. Emmert (Eds.), Confronting the Yugoslav controversies: A scholars' initiative (pp. 83-112). Central European Studies Series Purdue University Press.

Tanner, M. (2001). Croatia: A nation forged in War. New Haven, CT: Yale University Press.

Wachtel, A., \& Bennett, C. (2009). The Dissolution of Yugoslavia. In C. Ingrao \& T.A. Emmert (Eds.), Confronting the Yugoslav controversies: A scholars' initiative (pp. 12-47). Central European Studies Series Purdue University Press.

\section{About the authors:}

Aleksandar Djokic - MA in Political Sciences, Lecturer Assistant of the Department of Comparative Politics, Peoples' Friendship University of Russia (RUDN University) (e-mail: dzhokich_a@pfur.ru) (ORCID ID: 0000-0003-1897-5642)

Guillaume Pichelin - MA in Political Sciences, Peoples' Friendship University of Russia (RUDN University) and Sciences Po Bordeaux (e-mail: pichelin.guillaume@gmail.com) (ORCID ID: 0000-0001-8679-9391)

\section{Сведения об авторах:}

Джокич Александар - магистр политических наук, ассистент кафедры сравнительной политологии Российского университета дружбы народов (e-mail: dzhokich_a@pfur.ru) (ORCID ID: 0000-0003-1897-5642)

Пишлен Гийом - магистр политологии Российского университета дружбы народов и Института политических исследований Бордо (e-mail: pichelin.guillaume@gmail.com) (ORCID ID: 0000-0001-8679-9391) 